肝細胞肥大の毒性学的特徵の解明に向けた農薬の

ラット反復投与毒性試験結果データベースの構築

増田 茜, ${ }^{a}$ 増田雅美, ${ }^{a}$ 川野拓歩, ${ }^{a}$ 橘内陽子, ${ }^{a}$ 中山晴香, ${ }^{a}$ 中島宏之, ${ }^{a, b}$ 小島弘幸, ${ }^{c}$ 北村繁幸, ${ }^{d}$ 浦丸直人, ${ }^{d}$ 保坂卓臣, ${ }^{a}$ 佐々木崇光, ${ }^{a}$ 吉成浩一 $*, a, b$

\title{
Construction of the Database of Rat Repeated-dose Toxicity Tests of Pesticides for the Toxicological Characterization of Hepatocyte Hypertrophy
}

\author{
Akane Masuda, ${ }^{a}$ Miyabi Masuda, ${ }^{a}$ Takuya Kawano, ${ }^{a}$ Yoko Kitsunai, ${ }^{a}$ Haruka Nakayama, ${ }^{a}$ \\ Hiroyuki Nakajima, ${ }^{a, b}$ Hiroyuki Kojima, ${ }^{c}$ Shigeyuki Kitamura, ${ }^{d}$ Naoto Uramaru, ${ }^{d}$ \\ Takuomi Hosaka, ${ }^{a}$ Takamitsu Sasaki, ${ }^{a}$ and Kouichi Yoshinari ${ }^{*, a, b}$ \\ aDepartment of Molecular Toxicology, School of Pharmaceutical Sciences, University of Shizuoka; 52-1 Yada, \\ Suruga-ku, Shizuoka 422-8526, Japan: ${ }^{b}$ Division of Drug Metabolism and Molecular Toxicology, Graduate \\ School of Pharmaceutical Sciences, Tohoku University; 6-3 Aramaki-Aoba, Aoba-ku, Sendai 980-8578, \\ Japan: 'Department of Environmental and Health Sciences, Hokkaido Institute of Public Health; \\ Kita-19, Nishi-12, Kita-ku, Sapporo 060-0819, Japan: and ${ }^{d}$ Department of Health Biosciences, \\ Nihon Pharmaceutical University; 10281 Komuro, Ina-machi, \\ Kitaadachi-gun, Saitama 362-0806, Japan.
}

(Received November 8, 2016; Accepted December 28, 2016)

\begin{abstract}
Liver and hepatocyte hypertrophy can be induced by exposure to chemical compounds, but the mechanisms and toxicological characteristics of these phenomena have not yet been investigated extensively. In particular, it remains unclear whether the hepatocyte hypertrophy induced by chemical compounds should be judged as an adaptive response or an adverse effect. Thus, understanding of the toxicological characteristics of hepatocyte hypertrophy is of great importance to the safety evaluation of pesticides and other chemical compounds. To this end, we have constructed a database of potentially toxic pesticides. Using risk assessment reports of pesticides that are publicly available from the Food Safety Commission of Japan, we extracted all observations/findings that were based on 90-day subacute toxicity tests and 2year chronic toxicity and carcinogenicity tests in rats. Analysis of the database revealed that hepatocyte hypertrophy was observed for $37-47 \%$ of the pesticides investigated (varying depending on sex and testing period), and that centrilobular hepatocyte hypertrophy was the most frequent among the various types of hepatocyte hypertrophy in both the 90-day and 2-year studies. The database constructed in this study enables us to investigate the relationships between hepatocyte hypertrophy and other toxicological observations/findings, and thus will be useful for characterizing hepatocyte hypertrophy.
\end{abstract}

Key words — liver hypertrophy; hepatocyte hypertrophy; database; pesticide; chemical safety assessment

\begin{abstract}
緒
論

生体内に取り込まれた化学物質は, しばしば肝肥 大（肝重量増加）及び肝細胞肥大を引き起こす。化 学物質の安全性評価のために実施される実験動物を 用いた毒性試験においても, 肝肥大及び肝細胞肥大 は最も一般的に認められる影響の 1 つである．肝細
\end{abstract}

$a$ 静岡県立大学薬学部衛生分子毒性学分野, $b$ 東北大学 大学院薬学研究科薬物動態学分野, $c$ 北海道立衛生研究 所生活科学部, ${ }^{d}$ 日本薬科大学薬学部健康生命科学分野 *e-mail: yoshinari@u-shizuoka-ken.ac.jp
胞肥大は小葉中心性, 小葉中間性, 小葉周辺性及び 小葉びまん性に認められ，化学物質の種類により発 現部位は異なるが，実際には小葉中心性に認められ ることが多い。代表的な例として，げっ歯動物の肝 がんプロモーターで薬物代謝酵素誘導薬である抗て んかん薬フェノバルビタールは, ラットやマウスで 小葉中心性の肝細胞肥大を引き起こすことが知られ ている. ${ }^{1,2)}$

肝の小葉中心域ではシトクロム P450（P450）を 始めとする薬物代謝酵素の活性が高く，これらの酵 素を含む滑面小胞体の含量も多い。また，フェノバ 
ルビタールなどの薬物代謝酵素誘導薬が投与される と，P450の発現六進とともに滑面小胞体の増加が

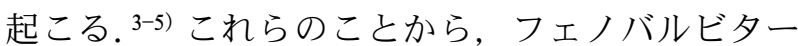
ルなどによる小葉中心性の肝細胞肥大は，薬物代謝 酵素誘導に伴い起こる二次的な変化（適応反応）と 考えられている. ${ }^{1)} し$ しながら，これは表現型と の関連から推察されているに過ぎず，小葉中心性肝 細胞肥大の分子レベルでの発現機序は全くわかって いない.

また, 肝肥大と肝細胞肥大が化学物質の有害影響 であるか否かの判定基準もかならずしも統一されて いない，上述のように，一般的には，肝細胞肥大は 薬物代謝酵素誘導に伴う適応反応であるとされてい る。しかし，壊死や炎症，細胞増殖などの明らかな 変性を伴う肝肥大は有害作用と考えられてい る. ${ }^{1,5-7)}$ また, 農薬の毒性試験結果の解析において マウスにおける肝重量増加（50\%以上）は肝腫瘍の 発生と関連するという研究結果もある。 ${ }^{8)}$ 以上をふ まえ, 諸外国では病理組織化学的な変化や壊死等の 明らかな毒性を認めない肝細胞肥大は，薬物代謝酵 素誘導に伴う二次的な変化（適応反応）の 1 つであ り，毒性影響ではないとされる. ${ }^{1,5,6)}$ 一方わが国で は，安全性を優先し，また肝肥大や肝細胞肥大が形 態学的及び病理組織的変化であることを考慮して, 化学物質の毒性影響であると判断されることがある.

わが国における食品中の化学物質（食品添加物や 農薬, 微生物, 環境污染物質等）のリスク評価は内 閣府食品安全委員会により行われ，各種毒性（安全 性）試験結果に基づいて最大無毒性量（no observed adverse effect level; NOAEL) 及び 1 日許容 摂取量 (acceptable daily intake; ADI）が設定され ている.しかしながら, 肝肥大や肝細胞肥大を化学 物質の毒性影響とみなすか否かに関するわが国と諸 外国間での認識の違いが，NOAEL 及び ADI の設 定值に国際的なずれを生じさせることがある。この ことは，食のグローバル化が進む現代において，経 済上の不利益だけでなく，農薬を始めとする化学物 質の摂取リスクに対する国民の認識に影響を与える 可能性がある.

以上のことより, 肝肥大及び肝細胞肥大の毒性学 的特徵や発現機序の解明が，化学物質の安全性評価 においてレギュラトリーサイエンスやリスクコミュ ニケーションの観点から必要であると考えられる.
現在使用されている多くの農薬に関しては，動物を 用いた毒性試験結果が食品安全委員会から農薬評価

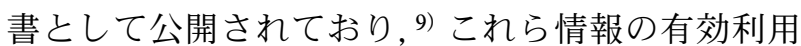
は上記問題の解決に有用と考えられる。そこで本研 究では，農薬評価書を利用したラット反復投与毒性 試験結果のデータベース構築を行った.

\section{方法}

\section{1. データベースの構築}

1-1. 農薬評価書の収集農薬評価書（低分子 有機化合物のみ）は，2014 年 10 月 1 日時点で内閣

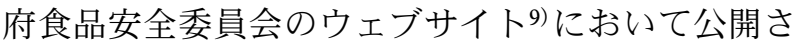
れていたものをすべて（266ファイル）入手し，本 研究の資料として用いた。全農薬に農薬名（英名） のアルファベット順で 3 桁のコード番号（001-266） を付し，ラット90 日間亜急性毒性試験及びラット 2 年間慢性毒性・発がん性併合試験（又は個別の反 復投与毒性試験と発がん性試験）の結果が適切に記 載されているものを本研究のデータとして採用した (90 日間試験；195 農薬， 2 年間試験；173 農薬). 採用した農薬には，さらに 5 桁のコード番号（90 日間試験：3M001-3M195，2 年間試験：2Y0012Y173）を付与した.

1-2. 毒性所見の抽出 1-1. で採用した各農薬 について，農薬評価書に記載されているラット 90 日間亜急性毒性試験及びラット 2 年間慢性毒性・発 がん性併合試験の全毒性所見（日本語表記）を，農 薬名 (和名), コード番号, 投与量, 雌雄と併せて Microsoft Excel のワークシートに入力した. 1 種類 の農薬について複数の試験結果が記載されている場 合には，毒性の所見数，肝毒性の有無，投与量の大 小，試験の詳細な記載の有無などを参考に，各農薬 について 1 つの試験結果のみを入力した.

1-3. 毒性所見のグループ化及びコード番号の付 与抽出した全毒性所見は，同一及び類似所見に ついてグループ化を行い， 3 階層のカテゴリーで分 類した (Supplementary Tables 1-42)。具体的に は, 第 1 カテゴリー（臓器/組織, 血液学, 血液生 化学, 尿/便, 外観/行動, 腫瘍/がん等), 第 2 カテ ゴリー (所見/徵候, 検査項目等), 第 3 カテゴリー （部位/細胞，毒性学的特徵等）の 3 階層とした。分 類した各毒性所見に 7 枌のコード番号を付け，1-3 桁目で第 1 カテゴリー，4-5 桁目で第 2 カテゴリー, 
6 桁目で第 3 カテゴリーを表現した。 7 桁目はさら に細分化する際の予備とした（現時点では 7 桁目は すべて 0 である)。なお，カテゴリーの分類方法や グループ化は，文献10,11)を参考にして行った．毒性 所見のコード番号は，ラット90日間亜急性毒性試 験とラット 2 年間慢性毒性・発がん性試験で得られ たすべての毒性所見で共通とした.

1-4. データシートの作成 Microsoft Excel の ワークシート上で，全農薬（1 行目）と全毒性所見 （A 列）のマトリクス表を作成した（Supplementary Fig. 1)。この表の各セルに，対応する毒性所見 が認められた場合には 1 ，認められなかった場合に は 0 を入力した。データシートは雌雄別に作成した.

2. 統計的データ解析 1-4. で作成したデータ シートを利用して，Microsoft Excel 上で統計解析 を行った。

\section{結果及び考察}

1. データベースの構築 本研究を開始した時 点で公開されていた 266 種類のすべての農薬評価書 を入手し，全農薬に 3 桁のコード番号（001-266） を付した。これらのうち，試験期間が 90 日間（13 週間）あるいは 2 年間以外，毒性所見の記載が不明 瞭，ラットの系統や雌雄が不明確なものを評価対象 農薬から除外した。最終的にラット 90 日間亜急性 毒性試験では 195 種類, ラット 2 年間慢性毒性/発 がん性併合試験では 173 種類の農薬評価書から毒性 所見デー夕の抽出を行った。同一の農薬評価書から 90 日間及び 2 年間の両試験結果を採用したものは 149 種類であった. デー夕抽出の結果, 重複したも のを除いた総所見数は 1702 種類となった。なお， 90 日間及び 2 年間試験に採用した農薬にそれぞれ 3M001-3M195 及び 2Y001-2Y173 のコード番号を 付与した.

次に, 全 1702 種類の毒性所見を 3 階層のカテゴ リーで分類した。まず，臓器/組織レベルや血液 学，血液生化学，腫瘍/がん等の大きなレベルで 42 種類に分類した（第 1 カテゴリー）（Table 1)。続 いて，所見/兆候，検査項目などのレベル（第 2 力 テゴリー), さらに部位/細胞レベル（第 3 カテゴ リー）で細分化し，同一の病理所見と考えられるが 評価書上の表記が微妙に異なるものを整理した。 そ の結果, 第 2 カテゴリーは 445 種類, 第 3 カテゴ
Table 1. The List of 1 st Categories

\begin{tabular}{clrl}
\hline \hline Code\# & \multicolumn{1}{c}{ Category name } & Code\# & \multicolumn{1}{c}{ Category name } \\
\hline 101 & Liver/Gallbladder & 122 & Lymph node \\
102 & Lung & 123 & Spleen \\
103 & Laryngopharynx & 124 & Thymus \\
104 & Nasal cavity & 125 & Thyroid gland \\
105 & Tooth & 126 & Parathyroid gland \\
106 & Salivary gland & 127 & Adrenal \\
107 & Stomach & 128 & Eye \\
108 & Small intestine & 129 & Harderian gland \\
109 & Large intestine & 130 & Ear \\
110 & Pancreas & 131 & Skeletal muscle \\
111 & Blood vessel & 132 & Bone/Articulation \\
112 & Heart & 133 & Thoracic cavity \\
113 & Kidney & 134 & Skin/Subcutis/Hair \\
114 & Urinary bladder/Ureter & 135 & Mammary gland \\
& /Urethra & 136 & Adipose tissue \\
115 & Testis/Seminal vesicle/ & 201 & Hematology \\
& Epididymis & 202 & Blood biochemistry \\
116 & Other male sex organs & 203 & Urine/Feces \\
117 & Ovary/Uterus & 301 & Body weight \\
118 & Other female sex organs & 302 & Appearance/Behavior \\
119 & Central nerve & 401 & Tumor/Cancer \\
120 & Peripheral nerve & & \\
121 & Bone marrow & & \\
& & &
\end{tabular}

リーは 872 種類となり, 総分類数は 1101 種類と なった. Table 2 に、「肝臓（第 1 カテゴリー)」に おいて認められた毒性所見（第 2 及び第 3 カテゴ リー）と，試験期間別，雌雄別のカテゴリー陽性数 のリストを示した。重量増加, 肝細胞肥大は多くの 農薬で認められたが，細胞死や細胞増殖は少なかっ た。また，肝細胞肥大との関連が示唆されている甲 状腺及び血液生化学の所見リス卜をそれぞれ Table 3 及び Table 4 に示した。 甲状腺については, 重量 増加と肥大/過形成が比較的多くの農薬で認められ たが，その他の所見が認められた農薬数は少なかつ た（Table 3). 血液生化学ではコレステロール増加 が多くの農薬で認められた (Table 4).

2. 統計解析 試験期間別及び雌雄別に, 第 1 カテゴリー毎の検出された所見数を算出した（Tables 5 and 6)。90日間試験では，雌雄ともに血液 生化学で最も多く, ついで血液学, 肝臓/胆囊, 外 観/行動，腎臓，体重，甲状腺，脾臓，尿/便，副腎 で，また雄性ラットでは精巣/精囊/精巣上体におい ても所見陽性数が多かった。一方，2 年間試験で は, 雌雄ともに肝㵴/胆囊, 血液学, 血液生化学に おいて特に多く, ついで腎臓，外観/行動，体重， 
Table 2. Findings/Observations in the Category of Liver/Gallbladder (101)

\begin{tabular}{|c|c|c|c|c|c|c|c|}
\hline \multirow[b]{2}{*}{ 1st category } & \multirow[b]{2}{*}{ 2nd category } & \multirow[b]{2}{*}{ 3rd category } & \multirow[b]{2}{*}{ Code\# } & \multicolumn{4}{|c|}{ Number of positive pesticides } \\
\hline & & & & \multicolumn{2}{|c|}{ Male } & \multicolumn{2}{|c|}{ Female } \\
\hline \multirow[t]{41}{*}{ Liver/Gallbladder } & Weight gain & Total & 1010100 & 121 & 89 & 124 & 84 \\
\hline & & Absolute weight & 1010110 & 70 & 61 & 82 & 52 \\
\hline & & Others & 1010190 & 10 & 7 & 11 & 2 \\
\hline & Weight loss & Total & 1010200 & 5 & 5 & 3 & 1 \\
\hline & & Absolute weight & 1010210 & 4 & 4 & 2 & 1 \\
\hline & & Relative weight & 1010220 & 3 & 4 & 1 & 0 \\
\hline & Hepatomegaly & Liver & 1010310 & 19 & 10 & 15 & 5 \\
\hline & & Centrilobular & 1010410 & 54 & 44 & 50 & 41 \\
\hline & & Midzonal & 1010420 & 1 & 1 & 1 & 1 \\
\hline & & Perilobular & 1010430 & 6 & 6 & 5 & 5 \\
\hline & & Diffuse & 1010440 & 37 & 24 & 36 & 23 \\
\hline & Fatty change/vacuolation & Total & 1010500 & 21 & 27 & 14 & 24 \\
\hline & & Centrilobular & 1010510 & 3 & 6 & 2 & 4 \\
\hline & & Midzonal & 1010520 & 1 & 1 & 1 & 2 \\
\hline & & Perilobular & 1010530 & 5 & 2 & 7 & 2 \\
\hline & & Diffuse & 1010540 & 0 & 6 & 0 & 6 \\
\hline & & Focal & 1010550 & 0 & 1 & 0 & 0 \\
\hline & & Loss & 1010560 & 2 & 0 & 0 & 0 \\
\hline & & Apoptosis & 1010610 & 0 & 0 & 0 & 1 \\
\hline & & Single cell & 1010620 & 9 & 2 & 8 & 3 \\
\hline & & Centrilobular & 1010630 & 1 & 1 & 1 & 2 \\
\hline & & Focal & 1010640 & 4 & 3 & 2 & 3 \\
\hline & & Others & 1010690 & 4 & 1 & 2 & 1 \\
\hline & Proliferation/hyperplasia & Total & 1010700 & 8 & 14 & 8 & 16 \\
\hline & & Hepatocyte & 1010710 & 3 & 5 & 2 & 4 \\
\hline & & Kupffer's cell & 1010720 & 1 & 1 & 1 & 1 \\
\hline & & Bile duct & 1010730 & 7 & 9 & 5 & 11 \\
\hline & & Others & 1010790 & 2 & 0 & 0 & 0 \\
\hline & Degeneration & Total & 1010800 & 9 & 24 & 5 & 7 \\
\hline & & Centrilobular & 1010810 & 0 & 1 & 1 & 1 \\
\hline & & Midzonal & 1010820 & 0 & 1 & 0 & 0 \\
\hline & & Perilobular & 1010830 & 2 & 4 & 0 & 1 \\
\hline & & Diffuse & 1010840 & 0 & 1 & 0 & 1 \\
\hline & & Focal & 1010850 & 1 & 2 & 0 & 1 \\
\hline & & Spongy degeneration & 1010860 & 0 & 15 & 0 & 0 \\
\hline & & Inclusion body & 1010870 & 2 & 2 & 0 & 0 \\
\hline & & Others & 1010890 & 4 & 4 & 4 & 4 \\
\hline & Pigment deposition & Total & 1010900 & 12 & 10 & 13 & 19 \\
\hline & & Centrilobular & 1010910 & 0 & 1 & 0 & 1 \\
\hline & & Diffuse & 1010920 & 0 & 1 & 0 & 1 \\
\hline & & Kupffer's cell & 1010930 & 5 & 3 & 5 & 9 \\
\hline
\end{tabular}


Table 2. (Continued)

\begin{tabular}{|c|c|c|c|c|c|c|c|}
\hline \multirow{3}{*}{1 st category } & \multirow{3}{*}{ 2nd category } & \multirow{3}{*}{ 3rd category } & \multirow{3}{*}{ Code\# } & \multicolumn{4}{|c|}{ Number of positive pesticides } \\
\hline & & & & \multicolumn{2}{|c|}{ Male } & \multicolumn{2}{|c|}{ Female } \\
\hline & & & & 90-day & 2-year & 90-day & 2-year \\
\hline \multirow[t]{34}{*}{ Liver/Gallbladder } & Inflammation/cell infiltration & Total & 1011000 & 7 & 9 & 4 & 14 \\
\hline & & Monocyte & 1011010 & 1 & 0 & 2 & 1 \\
\hline & & Foam cell & 1011020 & 1 & 1 & 1 & 3 \\
\hline & & Inflammation & 1011030 & 2 & 5 & 0 & 5 \\
\hline & & Fibrosis & 1011040 & 0 & 1 & 0 & 2 \\
\hline & & Others & 1011090 & 4 & 3 & 2 & 5 \\
\hline & Appearance & Total & 1011100 & 14 & 13 & 15 & 11 \\
\hline & & Discoloration (bleaching) & 1011110 & 0 & 3 & 0 & 2 \\
\hline & & Darkening & 1011120 & 10 & 5 & 13 & 5 \\
\hline & & Accentuated lobule & 1011130 & 3 & 1 & 2 & 3 \\
\hline & & Spot & 1011140 & 0 & 2 & 0 & 0 \\
\hline & & Surface & 1011150 & 0 & 1 & 0 & 1 \\
\hline & & Others & 1011190 & 2 & 2 & 1 & 2 \\
\hline & Altered foci & Total & 1011200 & 0 & 35 & 0 & 24 \\
\hline & & Eosinophilic & 1011210 & 0 & 21 & 0 & 17 \\
\hline & & Basophilic & 1011220 & 0 & 8 & 0 & 6 \\
\hline & & Clear cell & 1011230 & 0 & 7 & 0 & 3 \\
\hline & & Others & 1011290 & 0 & 10 & 0 & 3 \\
\hline & Altered bile duct & Dilatation & 1011310 & 1 & 2 & 1 & 7 \\
\hline & Congestion & Total & 1011400 & 0 & 3 & 0 & 4 \\
\hline & & Sinusoidal dilatation & 1011410 & 0 & 2 & 0 & 3 \\
\hline & & Congestion & 1011420 & 0 & 1 & 0 & 0 \\
\hline & & Peliosis & 1011430 & 0 & 0 & 0 & 1 \\
\hline & Enzyme & Total & 1011500 & 2 & 1 & 1 & 1 \\
\hline & & Increase, $\mathrm{EH}$ & 1011510 & 0 & 1 & 0 & 1 \\
\hline & & Increase, UGT & 1011520 & 0 & 1 & 0 & 1 \\
\hline & & Increase, GST & 1011530 & 0 & 1 & 0 & 1 \\
\hline & & Increase, $\mathrm{P} 450$ & 1011540 & 1 & 0 & 0 & 0 \\
\hline & & Increase, GGT & 1011550 & 1 & 0 & 1 & 0 \\
\hline & Abnormality of nucleus & Total & 1011600 & 4 & 0 & 2 & 0 \\
\hline & & Numerical & 1011610 & 1 & 0 & 0 & 2 \\
\hline & & Morphological & 1011620 & 3 & 0 & 2 & 0 \\
\hline & & Others & 1011690 & 1 & 0 & 1 & 0 \\
\hline & Miscellaneous & & 1019910 & 3 & 1 & 2 & 2 \\
\hline
\end{tabular}

甲状腺，尿/便，腫瘍/がんで所見陽性数が多かつ た。また，90日間試験と同様に，雄性ラットでは 多くの農薬において精巣/精囊/精巣上体の所見が認 められた。観察された所見に，試験期間の違いによ る大きな差は認められなかった.

試験期間別及び雌雄別に，第 3 カテゴリーの各所 見及び第 2 カテゴリー 1010400 (Liver/hepatocyte hypertrophy）の陽性農薬数を算出し，解析した全 農薬数 (90 日間では 195 農薬， 2 年間では 173 農薬)
のうち 20\%（90 日間では 39 農薬， 2 年間では 35 農薬）以上で認められた所見を，多いものから順に 並べた（Tables 7 and 8)。90 日間試験では，雌雄 ともに最も多く認められたのは体重増加抑制 （3010120）であり, 肝比重量増加 (1010120), 肝細 胞肥大 $(1010400,1010410)$ など肝藏の所見や，へ モグロビン濃度減少（2010520）やへマトクリット 值減少（2010620）など貧血の指標となる所見のほ か, 肝機能異常を表す $\gamma$-glutamyl transpeptidase 
Table 3. Findings/Observations in the Category of Thyroid Gland (125)

\begin{tabular}{|c|c|c|c|c|c|c|c|}
\hline \multirow{3}{*}{1 st category } & \multirow{3}{*}{ 2nd category } & \multirow{3}{*}{ 3rd category } & \multirow{3}{*}{ Code\# } & \multicolumn{4}{|c|}{ Number of positive pesticides } \\
\hline & & & & \multicolumn{2}{|c|}{ Male } & \multicolumn{2}{|c|}{ Female } \\
\hline & & & & 90-day & 2-year & 90-day & 2-year \\
\hline \multirow[t]{43}{*}{ Thyroid gland } & Weight gain & Total & 1250100 & 22 & 19 & 16 & 16 \\
\hline & & Absolute weight & 1250110 & 19 & 15 & 14 & 11 \\
\hline & & Relative weight & 1250120 & 21 & 16 & 16 & 16 \\
\hline & & Others & 1250190 & 1 & 0 & 0 & 0 \\
\hline & Weight loss & Total & 1250200 & 0 & 2 & 0 & 1 \\
\hline & & Absolute weight & 1250210 & 0 & 1 & 0 & 1 \\
\hline & & Relative weight & 1250220 & 0 & 1 & 0 & 0 \\
\hline & Hormone level change & Total & 1250300 & 12 & 7 & 11 & 5 \\
\hline & & Increase, $\mathrm{T} 3$ & 1250310 & 4 & 1 & 4 & 1 \\
\hline & & Decrease, T3 & 1250320 & 5 & 2 & 3 & 2 \\
\hline & & Increase, $\mathrm{T} 4$ & 1250330 & 3 & 0 & 2 & 0 \\
\hline & & Decrease, T4 & 1250340 & 8 & 4 & 6 & 3 \\
\hline & & Increase, $\mathrm{T} 4$ binding capacity & 1250350 & 1 & 1 & 1 & 1 \\
\hline & & Decrease, T4 binding potential & 1250360 & 1 & 0 & 1 & 0 \\
\hline & & Increase, TSH & 1250370 & 8 & 2 & 7 & 3 \\
\hline & Hypertrophy/hyperplasia & Total & 1250400 & 29 & 26 & 26 & 26 \\
\hline & & Thyroid gland & 1250410 & 5 & 6 & 5 & 1 \\
\hline & & Follicular epithelial cell hypertrophy & 1250420 & 23 & 12 & 20 & 13 \\
\hline & & Follicle increase/hypertrophy & 1250430 & 5 & 1 & 5 & 1 \\
\hline & & Follicular epithelial cell hyperplasia & 1250440 & 7 & 14 & 5 & 12 \\
\hline & & Parafollicular cell hyperplasia & 1250450 & 0 & 3 & 0 & 2 \\
\hline & & Follicular cyst & 1250460 & 1 & 4 & 0 & 5 \\
\hline & Vacuolation & Follicular cell & 1250510 & 2 & 2 & 2 & 2 \\
\hline & Cell death/inflammation & Total & 1250600 & 0 & 1 & 0 & 1 \\
\hline & & Inflammation & 1250610 & 0 & 1 & 0 & 1 \\
\hline & & Necrosis & 1250620 & 0 & 0 & 0 & 1 \\
\hline & Colloiddegeneration & Total & 1250700 & 3 & 11 & 3 & 11 \\
\hline & & Basification & 1250710 & 0 & 1 & 0 & 1 \\
\hline & & Aggregation & 1250720 & 2 & 1 & 1 & 1 \\
\hline & & Deficiency & 1250730 & 1 & 1 & 2 & 1 \\
\hline & & Others & 1250790 & 0 & 8 & 0 & 8 \\
\hline & Pigment deposition & Total & 1250800 & 0 & 4 & 0 & 3 \\
\hline & & Thyroid gland & 1250810 & 1 & 1 & 1 & 1 \\
\hline & & Follicular cell & 1250820 & 0 & 3 & 0 & 2 \\
\hline & Color tone change & Total & 1250900 & 1 & 2 & 1 & 1 \\
\hline & & Darkening & 1250910 & 0 & 2 & 0 & 1 \\
\hline & & Discoloration & 1250920 & 1 & 0 & 1 & 0 \\
\hline & Mineralization & Total & 1251000 & 0 & 3 & 0 & 4 \\
\hline & & Follicular cell & 1251010 & 0 & 1 & 0 & 2 \\
\hline & & Colloid & 1251020 & 0 & 2 & 0 & 2 \\
\hline & Miscellaneous & Total & 1259900 & 1 & 0 & 1 & 1 \\
\hline & & Thyroid gland & 1259910 & 0 & 0 & 0 & 1 \\
\hline & & Blood vessel & 1259920 & 1 & 0 & 1 & 0 \\
\hline
\end{tabular}


Table 4. Findings/Observations in the Category of Blood Biochemistry (202)

\begin{tabular}{|c|c|c|c|c|c|c|c|}
\hline \multirow{3}{*}{ 1st category } & \multirow{3}{*}{ 2nd category } & \multirow{3}{*}{ 3rd category } & \multirow{3}{*}{ Code\# } & \multicolumn{4}{|c|}{ Number of positive pesticides } \\
\hline & & & & \multicolumn{2}{|c|}{ Male } & \multicolumn{2}{|c|}{ Female } \\
\hline & & & & 90-day & 2-year & 90-day & 2-year \\
\hline \multirow[t]{43}{*}{ Blood biochemistry } & Total protein & Total & 2020100 & 70 & 34 & 55 & 33 \\
\hline & & Increase & 2020110 & 41 & 22 & 32 & 24 \\
\hline & & Decrease & 2020120 & 29 & 12 & 23 & 9 \\
\hline & Albumin & Total & 2020200 & 43 & 20 & 37 & 13 \\
\hline & & Increase & 2020210 & 31 & 14 & 14 & 8 \\
\hline & & Decrease & 2020220 & 12 & 6 & 23 & 5 \\
\hline & Albumin/globulin ratio & Total & 2020300 & 18 & 12 & 23 & 12 \\
\hline & & Increase & 2020310 & 13 & 6 & 9 & 3 \\
\hline & & Decrease & 2020320 & 5 & 6 & 14 & 9 \\
\hline & Globulin & Total & 2020400 & 42 & 20 & 39 & 24 \\
\hline & & Increase & 2020410 & 20 & 11 & 25 & 17 \\
\hline & & Decrease & 2020420 & 22 & 10 & 14 & 7 \\
\hline & & Decrease, IgA & 2020430 & 1 & 0 & 1 & 0 \\
\hline & & Decrease, $\mathrm{IgG}$ & 2020440 & 1 & 0 & 1 & 0 \\
\hline & Aspartate aminotransferase & Total & 2020500 & 24 & 10 & 20 & 7 \\
\hline & & Increase & 2020510 & 22 & 9 & 17 & 4 \\
\hline & & Decrease & 2020520 & 2 & 1 & 3 & 3 \\
\hline & Alanine aminotransferase & Total & 2020600 & 28 & 13 & 18 & 7 \\
\hline & & Increase & 2020610 & 26 & 12 & 15 & 6 \\
\hline & & Decrease & 2020620 & 2 & 1 & 3 & 1 \\
\hline & Lactate dehydrogenase & Total & 2020700 & 5 & 1 & 1 & 2 \\
\hline & & Increase & 2020710 & 3 & 0 & 0 & 1 \\
\hline & & Decrease & 2020720 & 2 & 1 & 1 & 1 \\
\hline & Glutamate dehydrogenase & Total & 2020800 & 1 & 1 & 0 & 1 \\
\hline & & Decrease & 2020810 & 0 & 1 & 0 & 1 \\
\hline & & Increase & 2020820 & 1 & 0 & 0 & 0 \\
\hline & Sorbitol dehydrogenase & Increase & 2020910 & 1 & 1 & 1 & 0 \\
\hline & Alkaline phosphatase & Total & 2021000 & 37 & 20 & 34 & 19 \\
\hline & & Increase & 2021010 & 33 & 16 & 28 & 16 \\
\hline & & Decrease & 2021020 & 4 & 4 & 6 & 3 \\
\hline & Bilirubin & Total & 2021100 & 20 & 10 & 20 & 11 \\
\hline & & Increase & 2021110 & 15 & 6 & 14 & 6 \\
\hline & & Decrease & 2021120 & 5 & 4 & 6 & 5 \\
\hline & $\gamma$-glutamyl transpeptidate & Total & 2021200 & 43 & 31 & 52 & 22 \\
\hline & $(\gamma$-GPT $)$ & Increase & 2021210 & 42 & 31 & 52 & 22 \\
\hline & & Decrease & 2021220 & 1 & 0 & 0 & 0 \\
\hline & Leucine aminopeptidase & Increase & 2021310 & 0 & 1 & 1 & 1 \\
\hline & Blood urea nitrogen & Total & 2021400 & 36 & 0 & 36 & 0 \\
\hline & & Increase & 2021410 & 36 & 24 & 35 & 24 \\
\hline & & Decrease & 2021420 & 0 & 0 & 1 & 0 \\
\hline & Creatinine & Total & 2021500 & 18 & 13 & 12 & 13 \\
\hline & & Increase & 2021510 & 16 & 10 & 8 & 9 \\
\hline & & Decrease & 2021520 & 2 & 3 & 4 & 4 \\
\hline
\end{tabular}


Table 4. (Continued)

\begin{tabular}{|c|c|c|c|c|c|c|c|}
\hline \multirow{3}{*}{ 1st category } & \multirow{3}{*}{ 2nd category } & \multirow{3}{*}{ 3rd category } & \multirow{3}{*}{ Code\# } & \multicolumn{4}{|c|}{ Number of positive pesticides } \\
\hline & & & & \multicolumn{2}{|c|}{ Male } & \multicolumn{2}{|c|}{ Female } \\
\hline & & & & 90-day & 2-year & 90-day & 2-year \\
\hline \multirow[t]{43}{*}{ Blood biochemistry } & Blood glucose & Total & 2021600 & 30 & 12 & 34 & 12 \\
\hline & & Increase & 2021610 & 3 & 3 & 8 & 2 \\
\hline & & Decrease & 2021620 & 27 & 9 & 26 & 10 \\
\hline & Cholesterol & Total & 2021700 & 77 & 43 & 79 & 59 \\
\hline & & Increase & 2021710 & 59 & 30 & 70 & 48 \\
\hline & & Decrease & 2021720 & 18 & 13 & 9 & 11 \\
\hline & & Increase, free cholesterol & 2021730 & 1 & 0 & 1 & 1 \\
\hline & Triglyceride & Total & 2021800 & 41 & 20 & 31 & 21 \\
\hline & & Increase & 2021810 & 6 & 5 & 7 & 8 \\
\hline & & Decrease & 2021820 & 35 & 15 & 24 & 13 \\
\hline & Phospholipid & Total & 2021900 & 10 & 5 & 10 & 5 \\
\hline & & Increase & 2021910 & 9 & 4 & 10 & 5 \\
\hline & & Decrease & 2021920 & 1 & 1 & 0 & 0 \\
\hline & Calcium & Total & 2022000 & 29 & 9 & 18 & 15 \\
\hline & & Increase & 2022010 & 20 & 8 & 10 & 12 \\
\hline & & Decrease & 2022020 & 9 & 1 & 8 & 3 \\
\hline & Phosphorus & Total & 2022100 & 21 & 0 & 22 & 0 \\
\hline & & Increase & 2022110 & 18 & 10 & 18 & 8 \\
\hline & & Decrease & 2022120 & 3 & 0 & 4 & 0 \\
\hline & Sodium & Total & 2022200 & 9 & 1 & 7 & 4 \\
\hline & & Increase & 2022210 & 5 & 0 & 2 & 3 \\
\hline & & Decrease & 2022220 & 4 & 1 & 5 & 1 \\
\hline & Potassium & Total & 2022300 & 19 & 2 & 16 & 3 \\
\hline & & Increase & 2022310 & 17 & 2 & 13 & 1 \\
\hline & & Decrease & 2022320 & 2 & 0 & 3 & 2 \\
\hline & Chlorine & Total & 2022400 & 20 & 5 & 19 & 6 \\
\hline & & Increase & 2022410 & 6 & 1 & 4 & 1 \\
\hline & & Decrease & 2022420 & 14 & 4 & 15 & 5 \\
\hline & Magnesium & Increase & 2022510 & 0 & 0 & 0 & 1 \\
\hline & Total iron-binding capacity & Increase & 2022610 & 0 & 0 & 0 & 1 \\
\hline & Free fatty acid & Total & 2022700 & 3 & 0 & 0 & 0 \\
\hline & & Increase & 2022710 & 1 & 0 & 0 & 0 \\
\hline & & Decrease & 2022720 & 2 & 0 & 0 & 0 \\
\hline & Creatine kinase & Total & 2022800 & 3 & 0 & 3 & 0 \\
\hline & & Increase & 2022810 & 2 & 0 & 2 & 0 \\
\hline & & Decrease & 2022820 & 1 & 0 & 1 & 0 \\
\hline & Uric acid & Total & 2022900 & 2 & 0 & 2 & 0 \\
\hline & & Increase & 2022910 & 1 & 0 & 1 & 0 \\
\hline & & Decrease & 2022920 & 1 & 0 & 1 & 0 \\
\hline & Ornithine carbamoyltransferase & Increase & 2023010 & 1 & 0 & 1 & 0 \\
\hline & $5^{\prime}$-Nucleotidase & Decrease & 2023110 & 0 & 0 & 1 & 0 \\
\hline & Total bile acid & Decrease & 2023210 & 0 & 0 & 1 & 0 \\
\hline & Cholinesterase & Decrease & 2023310 & 0 & 0 & 5 & 0 \\
\hline
\end{tabular}


Table 5. The Number of Positive Findings/Observations for Each 1st Category in 90-Day Repeated-dose Toxicity Tests

\begin{tabular}{|c|c|c|c|c|}
\hline \multicolumn{2}{|r|}{1 st category } & \multirow{2}{*}{$\begin{array}{l}\text { Number } \\
\text { of 3rd } \\
\text { categories }\end{array}$} & \multicolumn{2}{|c|}{$\begin{array}{l}\text { Number of } \\
\text { positives }\end{array}$} \\
\hline Code\# & Category name & & Male & Female \\
\hline 101 & Liver/Gallbladder & 80 & 741 & 694 \\
\hline 102 & Lung & 14 & 18 & 20 \\
\hline 103 & Laryngopharynx & 2 & 0 & 0 \\
\hline 104 & Nasal cavity & 12 & 1 & 2 \\
\hline 105 & Tooth & 9 & 5 & 2 \\
\hline 106 & Salivary gland & 15 & 11 & 7 \\
\hline 107 & Stomach & 36 & 24 & 28 \\
\hline 108 & Small intestine & 17 & 10 & 15 \\
\hline 109 & Large intestine & 12 & 12 & 12 \\
\hline 110 & Pancreas & 30 & 20 & 11 \\
\hline 111 & Blood vessel & 3 & 0 & 0 \\
\hline 112 & Heart & 19 & 29 & 27 \\
\hline 113 & Kidney & 85 & 355 & 255 \\
\hline 114 & $\begin{array}{l}\text { Urinary bladder/Ureter/ } \\
\text { Urethra }\end{array}$ & 16 & 18 & 16 \\
\hline 115 & $\begin{array}{l}\text { Testis/Seminal vesicle/ } \\
\text { Epididymis }\end{array}$ & 43 & 116 & 0 \\
\hline 116 & $\begin{array}{l}\text { Other male accessory sex } \\
\text { appendages }\end{array}$ & 9 & 6 & 0 \\
\hline 117 & Ovary/Uterus & 44 & 0 & 80 \\
\hline 118 & $\begin{array}{l}\text { Other female accessory sex } \\
\text { appendages }\end{array}$ & 6 & 0 & 3 \\
\hline 119 & Central nerve & 26 & 49 & 42 \\
\hline 120 & Peripheral nerve & 6 & 0 & 0 \\
\hline 121 & Bone marrow & 25 & 33 & 37 \\
\hline 122 & Lymph node & 24 & 16 & 16 \\
\hline 123 & Spleen & 26 & 173 & 174 \\
\hline 124 & Thymus & 12 & 23 & 24 \\
\hline 125 & Thyroid gland & 45 & 186 & 153 \\
\hline 126 & Parathyroid gland & 4 & 8 & 0 \\
\hline 127 & Adrenal & 31 & 112 & 132 \\
\hline 128 & Eye & 51 & 49 & 51 \\
\hline 129 & Harderian gland & 6 & 2 & 2 \\
\hline 130 & Ear & 1 & 0 & 2 \\
\hline 131 & Skeletal muscle & 9 & 3 & 4 \\
\hline 132 & Bone/Articulation & 22 & 3 & 5 \\
\hline 133 & Thoracic cavity & 2 & 0 & 0 \\
\hline 134 & Skin/Subcutis/Hair & 19 & 29 & 33 \\
\hline 135 & Mammary gland & 3 & 1 & 1 \\
\hline 136 & Adipose tissue & 8 & 2 & 3 \\
\hline 201 & Hematology & 85 & 1027 & 1032 \\
\hline 202 & Blood biochemistry & 86 & 1302 & 1189 \\
\hline 203 & Urine/Feces & 52 & 166 & 147 \\
\hline 301 & Body weight & 3 & 286 & 278 \\
\hline 302 & Appearance/Behavior & 58 & 423 & 452 \\
\hline 401 & Tumor/Cancer & 45 & 0 & 0 \\
\hline
\end{tabular}

Table 6. The Number of Positive Findings/Observations for Each 1st Category in 2-Year Repeated-dose Toxicity Tests

\begin{tabular}{|c|c|c|c|c|}
\hline \multicolumn{2}{|r|}{ 1st category } & \multirow{2}{*}{$\begin{array}{l}\text { Number } \\
\text { of 3rd } \\
\text { categories }\end{array}$} & \multicolumn{2}{|c|}{$\begin{array}{l}\text { Number of } \\
\text { positives }\end{array}$} \\
\hline Code\# & Category name & & Male & Female \\
\hline 101 & Liver/Gallbladder & 80 & 720 & 645 \\
\hline 102 & Lung & 14 & 27 & 25 \\
\hline 103 & Laryngopharynx & 2 & 2 & 2 \\
\hline 104 & Nasal cavity & 12 & 14 & 14 \\
\hline 105 & Tooth & 9 & 20 & 18 \\
\hline 106 & Salivary gland & 15 & 1 & 1 \\
\hline 107 & Stomach & 36 & 49 & 51 \\
\hline 108 & Small intestine & 17 & 9 & 10 \\
\hline 109 & Large intestine & 12 & 4 & 5 \\
\hline 110 & Pancreas & 30 & 32 & 26 \\
\hline 111 & Blood vessel & 3 & 4 & 2 \\
\hline 112 & Heart & 19 & 30 & 27 \\
\hline 113 & Kidney & 85 & 360 & 280 \\
\hline 114 & $\begin{array}{l}\text { Urinary bladder/Ureter/ } \\
\text { Urethra }\end{array}$ & 16 & 21 & 23 \\
\hline 115 & $\begin{array}{l}\text { Testis/Seminal vesicle/ } \\
\text { Epididymis }\end{array}$ & 43 & 110 & 0 \\
\hline 116 & $\begin{array}{l}\text { Other male accessory sex } \\
\text { appendages }\end{array}$ & 9 & 7 & 0 \\
\hline 117 & Ovary/Uterus & 44 & 0 & 68 \\
\hline 118 & $\begin{array}{l}\text { Other female accessory sex } \\
\text { appendages }\end{array}$ & 6 & 0 & 4 \\
\hline 119 & Central nerve & 26 & 32 & 37 \\
\hline 120 & Peripheral nerve & 6 & 19 & 19 \\
\hline 121 & Bone marrow & 25 & 2 & 2 \\
\hline 122 & Lymph node & 24 & 15 & 20 \\
\hline 123 & Spleen & 26 & 65 & 64 \\
\hline 124 & Thymus & 12 & 2 & 2 \\
\hline 125 & Thyroid gland & 45 & 179 & 163 \\
\hline 126 & Parathyroid gland & 4 & 11 & 9 \\
\hline 127 & Adrenal & 31 & 47 & 44 \\
\hline 128 & Eye & 51 & 82 & 97 \\
\hline 129 & Harderian gland & 6 & 2 & 7 \\
\hline 130 & Ear & 1 & 1 & 1 \\
\hline 131 & Skeletal muscle & 9 & 11 & 19 \\
\hline 132 & Bone/Articulation & 22 & 20 & 12 \\
\hline 133 & Thoracic cavity & 2 & 2 & 2 \\
\hline 134 & Skin/Subcutis/Hair & 19 & 27 & 44 \\
\hline 135 & Mammary gland & 3 & 2 & 0 \\
\hline 136 & Adipose tissue & 8 & 4 & 4 \\
\hline 201 & Hematology & 85 & 568 & 653 \\
\hline 202 & Blood biochemistry & 86 & 600 & 613 \\
\hline 203 & Urine/Feces & 52 & 136 & 116 \\
\hline 301 & Body weight & 3 & 262 & 286 \\
\hline 302 & Appearance/Behavior & 58 & 320 & 322 \\
\hline 401 & Tumor/Cancer & 45 & 119 & 95 \\
\hline
\end{tabular}


Table 7. The Ranking of Findings/Observations in 90-Day Repeated-dose Toxicity Tests

\begin{tabular}{|c|c|c|c|c|c|c|}
\hline \multirow{2}{*}{ Sex } & \multirow{2}{*}{ Rank } & \multicolumn{4}{|c|}{ Findings/Observations } & \multirow{2}{*}{$\begin{array}{c}\text { Number of } \\
\text { positives }\end{array}$} \\
\hline & & Code\# & 1st category & 2nd category & 3rd category & \\
\hline \multirow{12}{*}{ Male } & 1 & 3010120 & Body weight & Weight loss & Suppression of gain & 141 \\
\hline & 2 & 1010120 & Liver/Gallbladder & Weight gain & Relative weight & 116 \\
\hline & 3 & 3021020 & Appearance/behavior & Food intake & Decrease & 97 \\
\hline & 4 & 1010400 & Liver/Gallbladder & Hepatocyte hypertrophy & - & 94 \\
\hline & 5 & 2010520 & Hematology & Hemoglobin concentration & Decrease & 71 \\
\hline & 6 & 1010110 & Liver/Gallbladder & Weight gain & Absolute weight & 70 \\
\hline & 7 & 2010620 & Hematology & Hematocrit value & Decrease & 62 \\
\hline & 8 & 2021710 & Blood biochemistry & Cholesterol & Increase & 59 \\
\hline & 9 & 1130120 & Kidney & Weight gain & Relative weight & 58 \\
\hline & 10 & 1010410 & Liver/Gallbladder & Hepatocyte hypertrophy & Centrilobular & 54 \\
\hline & 10 & 2010120 & Hematology & Red blood cell & Decrease & 54 \\
\hline & 12 & 2021210 & Blood biochemistry & $\gamma$-GTP & Increase & 42 \\
\hline \multirow{12}{*}{ Female } & 1 & 3010120 & Body weight & Weight loss & Suppression of gain & 137 \\
\hline & 2 & 1010120 & Liver/Gallbladder & Weight gain & Relative weight & 120 \\
\hline & 3 & 3021020 & Appearance/behavior & Food intake & Decrease & 101 \\
\hline & 4 & 1010400 & Liver/Gallbladder & Hepatocyte hypertrophy & - & 87 \\
\hline & 5 & 1010110 & Liver/Gallbladder & Weight gain & Absolute weight & 82 \\
\hline & 6 & 2010520 & Hematology & Hemoglobin concentration & Decrease & 75 \\
\hline & 7 & 2021710 & Blood biochemistry & Cholesterol & Increase & 70 \\
\hline & 7 & 2010620 & Hematology & Hematocrit value & Decrease & 70 \\
\hline & 9 & 2021210 & Blood biochemistry & $\gamma$-GTP & Increase & 52 \\
\hline & 10 & 1130120 & Kidney & Weight gain & Relative weight & 51 \\
\hline & 11 & 1010410 & Liver/Gallbladder & Hepatocyte hypertrophy & Centrilobular & 50 \\
\hline & 11 & 2010120 & Hematology & Red blood cell & Decrease & 50 \\
\hline
\end{tabular}

Findings/observations belonging to 3rd categories except \#1010400 (liver-hepatocyte hypertrophy, which belongs to 2 nd category) that were positive in 90 -day tests were counted and those that were positives for more than $20 \%$ of all 195 pesticides are shown.

（ $\gamma$-GTP）増加（2021210）も含まれていた。雌雄で 大きな違いは認められなかった。

2 年間試験でも 90 日間試験と同様，体重増加抑 制（3010120）が最も多く認められた。また, 肝比 重量増加 (1010120), 肝細胞肥大 (1010400) やへ モグロビン濃度減少 (2010520), ヘマトクリット值 減少（2010620）などが含まれていた，以上の結果 から，抽出された各所見に大きな性差は認められ ず，また 90 日間と 2 年間試験の間にも大きな違い は認められなかった。

試験期間別及び雌雄別に，肝臓の絶対又は相対重 量増加が陽性・陰性の場合に分けて，部位別の肝細 胞肥大の陽性数を算出した (Table 9). Total の数 字は，それぞれの場合において，いずれかの肝細胞 肥大が認められた農薬数を示している. 認められた 肝細胞肥大の部位が投与量によって異なる農薬が あったため, 合計の数字は肝細胞肥大の部位毎の陽 性数を足したもの（小葉中心性十小葉中間性十小葉
周辺性十小葉びまん性）とは異なっている. なお， 部位の記載がない場合には小葉びまん性としてカウ ントした.

90 日間試験では, 小葉中心性肝細胞肥大が最も 多く認められ，雄性ラットでは 195 農薬中 54 農 薬, 雌性ラットでは 50 農薬において認められた。 ついで小葉びまん性肝細胞肥大が多く, 雄性ラット で 37 農薬，雌性ラットで 36 農薬において認められ た。また肝重量増加が陽性の農薬では, 約 3 分の 2 の農薬で肝細胞肥大も陽性であった。

2 年間試験における肝細胞肥大についても，90 日 間試験の場合と同様に，雄性ラットでは 173 農薬中 44 農薬，雌性ラットでは 41 農薬で認められた小葉 中心性肝細胞肥大が最も多く，ついで雄性ラットで 24 農薬, 雌性ラットで 23 農薬において認められて いた小葉びまん性肝細胞肥大が多かった。また肝重 量増加が認められた農薬では, 半数以上で肝細胞肥 大が認められた。 
Table 8. The Ranking of Findings/Observations in 2-Year Repeated-dose Toxicity Tests

\begin{tabular}{|c|c|c|c|c|c|c|}
\hline \multirow{2}{*}{ Sex } & \multirow{2}{*}{ Rank } & \multicolumn{4}{|c|}{ Findings/Observations } & \multirow{2}{*}{$\begin{array}{c}\text { Number of } \\
\text { positives }\end{array}$} \\
\hline & & Code\# & 1 st category & 2nd category & 3rd category & \\
\hline \multirow{9}{*}{ Male } & 1 & 3010120 & Weight & Weight loss & Suppression of gain & 127 \\
\hline & 2 & 1010120 & Liver/Gallbladder & Weight gain & Relative weight & 85 \\
\hline & 3 & 3021020 & Appearance/behavior & Food intake & Decrease & 70 \\
\hline & 4 & 1010400 & Liver/Gallbladder & Hepatocyte hypertrophy & - & 67 \\
\hline & 5 & 1010110 & Liver/Gallbladder & Weight gain & Absolute weight & 61 \\
\hline & 6 & 2010520 & Hematology & Hemoglobin concentration & Decrease & 48 \\
\hline & 7 & 1010410 & Liver/Gallbladder & Hepatocyte hypertrophy & Centrilobular & 44 \\
\hline & 7 & 2010620 & Hematology & Hematocrit value & Decrease & 44 \\
\hline & 9 & 1130120 & Kidney & Weight gain & Relative weight & 43 \\
\hline \multirow{12}{*}{ Female } & 1 & 3010120 & Weight & Weight loss & Suppression of gain & 140 \\
\hline & 2 & 1010120 & Liver/Gallbladder & Weight gain & Relative weight & 79 \\
\hline & 3 & 3021020 & Appearance/behavior & Food intake & Decrease & 75 \\
\hline & 4 & 1010400 & Liver/Gallbladder & Hepatocyte hypertrophy & - & 64 \\
\hline & 5 & 2010520 & Hematology & Hemoglobin concentration & Decrease & 57 \\
\hline & 6 & 2010620 & Hematology & Hematocrit value & Decrease & 56 \\
\hline & 7 & 1010110 & Liver/Gallbladder & Weight gain & Absolute weight & 52 \\
\hline & 8 & 2021710 & Blood biochemistry & Cholesterol & Increase & 48 \\
\hline & 9 & 1010410 & Liver/Gallbladder & Hepatocyte hypertrophy & Centrilobular & 41 \\
\hline & 10 & 2010120 & Hematology & Red blood cell & Decrease & 40 \\
\hline & 11 & 1130120 & Kidney & Weight gain & Relative weight & 39 \\
\hline & 12 & 3021040 & Appearance/behavior & Food intake & Decrease, food efficiency & 35 \\
\hline
\end{tabular}

Findings/observations belonging to 3rd categories except \#1010400 (liver-hepatocyte hypertrophy, which belongs to 2nd category) that were positive in 2-year tests were counted and those that were positives for more than $20 \%$ of all 173 pesticides are shown.

Table 9. Hepatocyte Hypertrophy and Liver Weight Gain in 90-Day and 2-Year Repeated-dose Toxicity Tests

\begin{tabular}{|c|c|c|c|c|c|c|c|}
\hline \multirow{2}{*}{ Sex } & \multirow{2}{*}{\multicolumn{2}{|c|}{ Liver/weight gain }} & \multicolumn{4}{|c|}{ Hepatocyte hypertrophy } & \multirow{2}{*}{ Total } \\
\hline & & & Centrilobular & Midzonal & Perilobular & Diffuse & \\
\hline \multicolumn{8}{|l|}{ 90-day } \\
\hline \multirow{4}{*}{ Male } & \multirow{2}{*}{ Absolute weight } & Positive & 28 & 1 & 4 & 23 & $52(70)$ \\
\hline & & Negative & 26 & 0 & 2 & 14 & $42(125)$ \\
\hline & \multirow{2}{*}{ Relative weight } & Positive & 45 & 1 & 6 & 34 & $82(116)$ \\
\hline & & Negative & 9 & 0 & 0 & 3 & $12(79)$ \\
\hline \multirow{4}{*}{ Female } & \multirow{2}{*}{ Absolute weight } & Positive & 31 & 1 & 4 & 26 & $57(82)$ \\
\hline & & Negative & 19 & 0 & 1 & 10 & $30(113)$ \\
\hline & \multirow{2}{*}{ Relative weight } & Positive & 46 & 1 & 5 & 34 & $81(120)$ \\
\hline & & Negative & 4 & 0 & 0 & 2 & $6(75)$ \\
\hline \multicolumn{8}{|l|}{ 2-year } \\
\hline \multirow{4}{*}{ Male } & \multirow{2}{*}{ Absolute weight } & Positive & 28 & 0 & 5 & 13 & $42(61)$ \\
\hline & & Negative & 16 & 1 & 1 & 11 & $25(112)$ \\
\hline & \multirow{2}{*}{ Relative weight } & Positive & 33 & 1 & 5 & 17 & $51(85)$ \\
\hline & & Negative & 11 & 0 & 1 & 7 & $16(88)$ \\
\hline \multirow{4}{*}{ Female } & \multirow{2}{*}{ Absolute weight } & Positive & 26 & 0 & 2 & 10 & $36(52)$ \\
\hline & & Negative & 15 & 1 & 3 & 13 & $28(121)$ \\
\hline & \multirow{2}{*}{ Relative weight } & Positive & 30 & 1 & 3 & 17 & $48(79)$ \\
\hline & & Negative & 11 & 0 & 2 & 6 & $16(94)$ \\
\hline
\end{tabular}

"Total" represents the number of pesticides that were positive in any "hepatocyte hypertrophy" for absolute or relative weight gain-positive or -negative compounds. The numbers in parentheses represent the numbers of pesticides that were positive or negative for each of absolute or relative weight gain in all (195 for 90-day, 173 for 2-year) pesticides. 
現在，農薬評価書におけるラット 90 日間及び 2 年間試験では薬物代謝酵素誘導に関する記述はほと んどない。このため, 肝細胞肥大と酵素誘導との係 わりについて農薬評価書データだけで詳細な考察を することは困難である。また反復投与毒性試験では 様々な毒性機序が複雑に係わり合っており，一面的 なアプローチでは発現する毒性所見やその機序の予 測・特定は難しい。 今回構築したデータベースを用 いて, 統計学的手法や, 酵素誘導に関するインビト 口試験結果を取り入れながら更なる解析を実施する ことで, 肝細胞肥大と酵素誘導の関連性並びに肝細 胞肥大の毒性学的特徵づけが可能になると考えてい る.

\section{結論}

肝細胞肥大の発現機序や毒性学的意義の解明に向 けて，本研究では，公開されている毒性試験情報を 利用して，ラット 2 年間慢性毒性・発がん性併合試 験結果（173 農薬）及びラット90日間亜急性毒性 試験結果（195 農薬）から合計 1702 の毒性所見を 抽出し, 雌雄別に毒性試験結果データベースを構築 した，そして，全毒性所見を 3 階層のカテゴリーで グループ化し，それぞれにコード番号を付与した。 これらにより，既知の膨大な毒性試験結果に基づい て, 肝細胞肥大や肝肥大の特徵の解析を効率的に行 うことができるようになった。

謝辞本研究の一部は, 内閣府食品安全委員会 食品健康影響評価技術研究（平成 25-26 年度 : 課題 番号 1302）及び日本化学工業協会が推進する LRI (Long-range Research Initiative; 化学物質の環境影 響および安全性に関する長期自主研究：課題番号 13_PT01-03-2）の支援を受けて実施された。農薬 評価書のデータ入力にご協力頂いた野表知世氏，飯 塚 薰氏（東北大学）及び中山智恵氏（静岡県立大 学)，並びに英文校閲にご協力頂いた Philip Hawke 氏（静岡県立大学）に感謝いたします。
Supplementary materials この論文のオンライ ンに Supplementary materials（電子付録）を含ん でいます。

\section{REFERENCES}

1) Hall A. P., Elcombe C. R., Foster J. R., Harada T., Kaufmann W., Knipple A., Küttler K., Malarkey D. E., Maronpot R. R., Nishikawa A., Nolte T., Schulte A., Strauss V., York M. J., Toxicol. Pathol., 40, 971-994 (2012).

2) Whysner J., Ross P. M., Williams G. M., Pharmacol. Ther., 71, 153-191 (1996).

3) Okey A. B., Pharmacol. Ther., 45, 241-298 (1990).

4) Handschin C., Meyer U. A., Pharmacol. Rev., 55, 649-673 (2003).

5) Maronpot R. R., Yoshizawa K., Nyska A., Harada T., Flake G., Mueller G., Singh B., Ward J. M., Toxicol. Pathol., 38, 776-795 (2010) .

6) Yoshida M., Umemura T., Kojima H., Inoue K., Takahashi M., Uramaru N., Kitamura S., Abe K., Tohkin M., Ozawa S., Yoshinari K., Food Hyg. Saf. Sci., 56, 42-48 (2015) .

7) Butler W. H., Toxicol. Pathol., 24, 484-492 (1996) .

8) Carmichael N. G., Enzmann H., Pate I., Waechter F., Environ. Health Perspect., 105, 1196-1203 (1997).

9) Cabinet Office, Government of Japan Food Safety Commission. "Risk Assessment.": $\langle$ https://www.fsc.go.jp/hyouka/〉, cited 16 December, 2016.

10) Nishikawa S., Yamashita T., Imai T., Yoshida M., Sakuratani Y., Yamada J., Maekawa A., Hayashi M., J. Toxicol. Sci., 35, E1-E8 (2010) .

11) “Ito's Toxicologic Pathology," ed. by Takahashi M., Fukushima S., Maruzen Co., Tokyo, 2013. 